\title{
Analisis Jaringan Saraf Tiruan Pengenalan Pola Huruf Hiragana dengan Model Jaringan Perceptron
}

\author{
Irfan Ramadhani $^{1}$, Selly Handik Pratiwi ${ }^{2}$, Anik Nur Handayani ${ }^{3}$ \\ Universitas Negeri Malang \\ 1irfanptic2011@gmail.com, ${ }^{2}$ sellyhandikpratiwi@gmail.com, ${ }^{3}$ Aniknur.ft@um.ac.id
}

\begin{abstract}
ABSTRAK. Artikel ini membahas mengenai program visual basic untuk mengenali dan menganalisis pola huruf hiraganaMa $\mathrm{Mi} \mathrm{Mu}$ Me dan Mo Pengenalan pola huruf hiragana tersebut memiliki tujuan untuk pengembangan pengenalan pola huruf hiragana yang dimana dalam pendidikan bahasa jepang sudah banyak masuk ke dalam susunan mata pelajaran muatan lokal dalam tingkat sekolah menengah atas sehingga dapat membantu siswa dalam pengenalan pola-pola huruf hiragana. Selain itu tujuan penelitian ini adalah membandingkan keakuratan perhitunga excel dengan hasil program. Metode yang digunakan dalam penelitian ini adalah model jaringan perceptron. Analisis dilakukan dengan berdasarkan nilai alpha dan threshold dari tiap-tiap pola yang dilakukan menggunakan excel dan implementasinya dalam program visual basicHasil dari penelitian ini adalah keakuratan nilai dari excel dan juga program.
\end{abstract}

Kata Kunci : Jaringan Saraf Tiruan, Perceptron, Pola Huruf Hiragana

\section{PENDAHULUAN}

Kecerdasan Buatan/Artificial Intelegence (AI) merupakan salah satu bagian ilmu komputer yang membuat agar mesin (komputer) dapat melakukan pekerjaan seperti dan sebaik yang dilakukan oleh manusia, misalnya saat dokter atau pakar penyakit tidak dapat berkomunikasi langsung dengan pasien maka mesin-mesin cerdas yang dikelola oleh komputer mampu mengatasi permasalahan seperti dengan sang pakar (Asri, 2011)

Jaringan Saraf Tiruan (JST) atau Artificial Neural Network merupakan suatu pendekatan yang berbeda dari metode AI lainnya . JST merupakan suatu model kecerdasan yang diilhami dari struktur otak manusia dan kemudian diimplementasikan menggunakan program komputer yang mampu menyelesaikan sejumlah proses perhitungan selama proses pembelajaran berlangsung (Septiarini, 2012).

Ada beberapa metode yang dapat digunakan untuk melakukan analisa dengan jaringan syaraf tiruanyaitu: metode Hebb, Perceptron, dan Backpropagation. Perceptron merupakan bentuk jaringan syaraf yang sederhana, biasanya digunakan untuk mengklasifikasikan suatu tipe pola tertentu yang sering dikenal dengan pemisahan secara linear, sehingga perceptron berguna sebagai pengklasifi-kasian objek yang salah satunya adalah pola huruf hiragana Ma (ま), Mi (み), Mu (む), Me (め) dan Mo (も). Pada umumnya, siswa-siswa SMA merasakesulitan mempelajari bahasa asing, contohnya bahasa Jepang.Dalam mempelajaribahasa Jepang, kesulitan yang sering dialami siswa meliputi menulis, membaca, dan menghafal kosakata (Kurinawan, 2015).

Pengembangan pengenalan pola huruf hiragana dengan menggunakan metode perceptron ini memiliki tujuan untuk memecahkan permasalahan yang dialami oleh siswa sekolah menengah atas dalam belajar bahasa jepang. Perceptron dilatih dengan menggunakan huruf hiragana Ma (ま), Mi (み), Mu (む), Me (め) dan Mo (も) yang diberikan secara berulang ulang selama latihan. Setiap pola yang diberikan merupakan pasangan pola masukan dan pola yang diinginkan sebagai target. Demikian dilakukan berulang ulang sampai dihasilkan keluaran yang sesuai dengan hasil yang diinginkan. Selain itu tujuan dari penelitian ini untuk membuktikan keakuratan hasil perhitungan excel dan juga perhitungan menggunakan program.

\section{METODE}

Metode yang digunakan dalam pengembangan ini adalah jaringan syaraf tiruan dengan menggunakan perceptron. Model ini merupakan model yang memiliki aplikasi danpelatihan yang lebih baik pada era tersebut. Perceptron merupakan salah satu bentukjaringan syaraf tiruan yang sederhana. Perceptron biasanya digunakan untukmengklasifikasikan suatu tipe pola tertentu yang sering dikenal dengan pemisahansecara linear. Pada dasarnya, jaringan syaraf perceptron dengan satu lapisan memilikibobot yang dapat diatur dan suatu nilai ambang atau threshold (David, 2011).Tujuan dari perceptron ini adalah mengklasifikasikan setiap pola input kedalam kelas tertentu. Apabila outputnya +1 , maka input yang diberikantermasuk kelas tertentu, sebaliknya jika outputnya -1, maka input yangdiberikan tidak masuk dalam kelas tertentu (Pujiyanta, 2009).Algoritma perceptron memiliki enam langkah yang digunakan untuk menemukan sebuah pola (Afriyanti, 2010) yaitu :

Langkah pertama: Lakukan Inisialisasi bobot $\left(w_{i}\right)$ dan bias $(b), \mathrm{w}_{\mathrm{i}}=\mathrm{b}=0$. Lalu Tentukan laju pemahaman ( $\alpha$ ). Untuk nilai $\alpha=1$. 
Langkah kedua: Lakukan pengecekan untuk semua vektor yang misclassification.

Langkah ketiga: Jika hasilnya terjadi misclassification dihitung dengan langkah aktivasi.

Langkah keempat: Jika hasilnya bernilai negatif, maka terjadi miss classification dan kalikan hasilnya dengan negatif learning rate. Kemudiah hasilnya disimpan dalam bentuk matriks untuk seluruh inputan yang miss clasification.

Langkah kelima: Kemudian lakukan perubahan bobot yang baru dengan menggunakan rumus :

$$
\begin{aligned}
& W_{i}(\text { baru })=W_{i}(\text { lama })+\Delta \mathrm{w}(\mathrm{i}=1, \ldots, \mathrm{n}) \text { dengan } \Delta \mathrm{w}=\alpha \mathrm{t} \mathrm{x}_{i} \\
& b(\text { baru })=b(\text { lama })+\Delta \mathrm{b} \text { dengan } \Delta \mathrm{b}=\alpha \mathrm{t}
\end{aligned}
$$

Langkah keenam: Lakukan pengulangan dari langkah kedua hingga tidak ada lagi vector yang misclassification.

Algoritma di atas dapat digunakan baik untuk input bipolar maupun biner, dengan bipolar target, nilai ambang tetap, dan bias yang bisa diatur. Nilai ambang disini tidak memainkan peranan seperti dalam fungsi undak. Sehingga keduanya (bias dan nilai ambang) di perlukan. Algoritma ini tidak terlalu sensitive terhadap nilai inisialisasi bobot (nilai awal bobot) maupun terhadap laju pelatihan (Hartantri dan Pujiyanta, 2014).

\section{A. Penentuan Nilai Inputan(x)}

Pada pengenalan pola huruf hiragana memiliki lima inputan yaitu ma,mi,mu,me dan mo. Selanjutnya pada pola inputan masing-masing memiliki target (t) yang berbeda sesuai pola yang ditetapkan. Setiap pola diatur dengan bobot $(\mathrm{w})$ awal $=0$ serta bias $(\mathrm{b})$ awal $=0$. Setiap vektor masukan (pola 1 sampai 5) mempunyai matrik $(14 \times 14)=196$ matriks. Untuk urutan pembacaan pola pada gambar dibawah dibaca dari urutan kolom nomor 1 kiri ke kanan sampai dengan kolom paling bawah. Pola huruf Hiragama bisa dilihat pada Gambar 1.
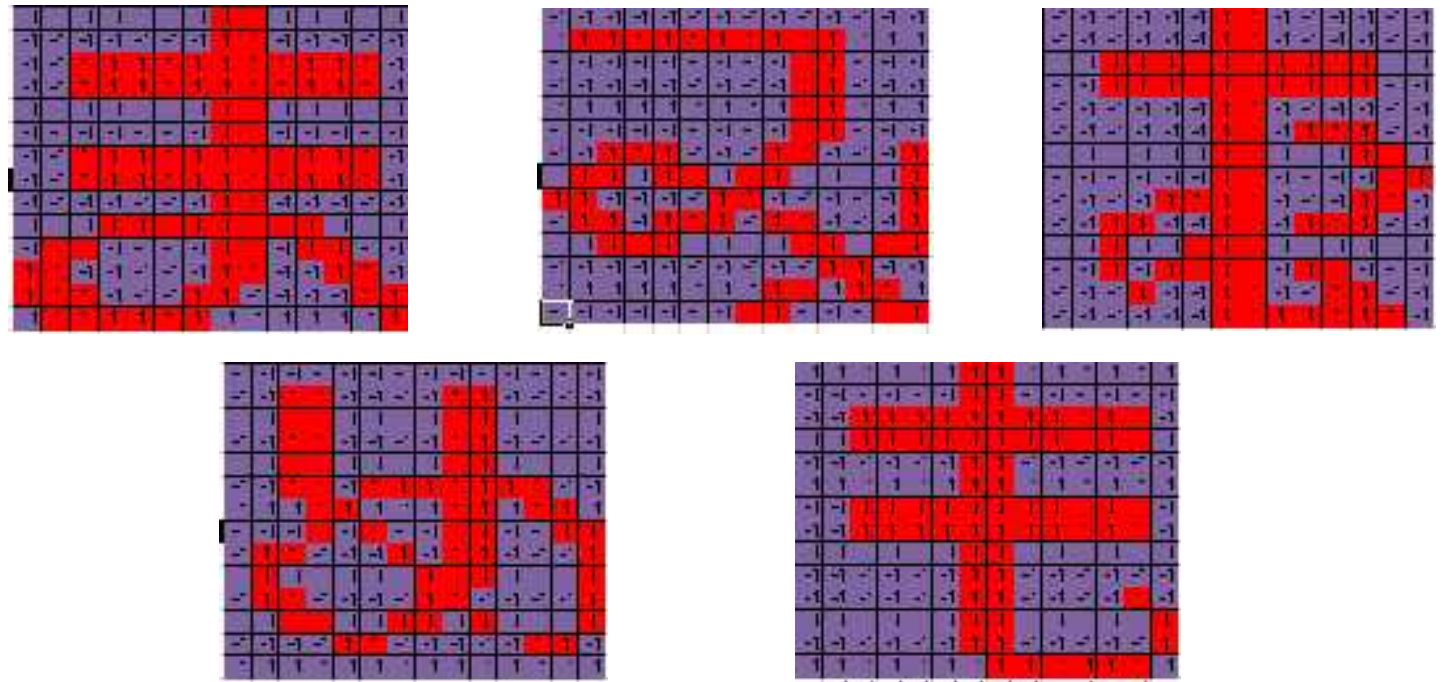

Gambar 1. Pola Huruf Hiragana Ma, Mi, Mu, Me, dan Mo

\section{B. Penentuan Nilai Target $(t)$}

Penentuan Nilai target $(\mathrm{t})$ pada ke-lima pola huruf hiragana ma,mi,mu,me dan mo ditunjukkan pada Tabel 1.

Tabel 1. Nilai Target (t) Pada lima pola huruf

\begin{tabular}{cccccc}
\hline $\begin{array}{c}\text { Pola } \\
\text { Masukan }\end{array}$ & $\begin{array}{c}\text { Nilai } \\
(\mathbf{t 1})\end{array}$ & $\begin{array}{c}\text { Nilai } \\
(\mathbf{t} 2)\end{array}$ & $\begin{array}{c}\text { Nilai } \\
(\mathbf{t 3})\end{array}$ & $\begin{array}{c}\text { Nilai } \\
(\mathbf{t} 4)\end{array}$ & $\begin{array}{c}\text { Nilai } \\
(\mathbf{t} 5)\end{array}$ \\
\hline $\mathrm{Ma}$ & 1 & -1 & -1 & -1 & -1 \\
$\mathrm{Mi}$ & -1 & 1 & -1 & -1 & -1 \\
$\mathrm{Mu}$ & -1 & -1 & 1 & -1 & -1 \\
$\mathrm{Me}$ & -1 & -1 & -1 & 1 & -1 \\
$\mathrm{Mo}$ & -1 & -1 & -1 & -1 & 1 \\
\hline
\end{tabular}


Selanjutnya, pemodelan jaringan perceptron dibentuk dan keluaran dari jaringan perceptron $(f(n e t)$ atau $y)$ yang dibuat pun harus dihitung. Guna mendapatkan bobot $(w)$ dan bias $(b)$ yang diinginkan, program perceptron harus dilatih. Setelah mendapatkan bobot $(w)$ dan bias (b) yang diinginkan, output yang diperoleh dari pemrograman perceptron $(f(n e t)$ atau $y)$ dibandingkan dengan target $(t)$ yang telah ditentukan.

C. Penentuan Nilai Target $(t)$

Perhitungan untuk nilai aktivasi unit masukan $x_{i}=s_{i}(i=1, \ldots, n)$. Dihitung respon unit keluaran: net $=+$ $b$.

\section{HASIL DAN PEMBAHASAN}

Perhitungan manual kelima huruf hiragana ma, mi, mu, me dan mo menggunakan program excel untuk mencari iterasi atau pengulangan dalam pengenalan pola huruf hiragana yang disesuaikan dengan metode perceptron. Perhitungan pengenalan pola huruf hiragana dengan data input, yakni: nilai bobot $(w)=0, \quad$ nilai alpha $(\alpha)=1$, nilai threshold $(\theta) \quad=0$, nilai bias $(b)=0$. Perhitungan manual ini memiliki tujuan untuk mencari iterasi atau pengulangan dalam mengenali pola huruf hiragana ma, mi, mu, me dan mo yang disesuaikan dengan target $(\mathrm{t})$ yang ditunjukkan oleh nilai $\mathrm{f}($ net) atau $\mathrm{y}$.

\section{A. Pola Huruf Hiragana Ma dalam Excel}

\begin{tabular}{|c|c|c|c|c|c|}
\hline & $b=s$ & tange: & $a^{\prime} \bar{z}$ & net & y \\
\hline & & & & & \\
\hline Pcla 1 & 1 & 1 & 1 & {[} & 0 \\
\hline Fola 2 & 1 & -1 & 1 & 7 & 1 \\
\hline Fola 3 & 1 & -1 & 1 & 34 & 1 \\
\hline Fola 4 & 1 & -1 & 1 & -49 & - \\
\hline Fola 5 & 1 & -1 & 1 & -13 & $=$ \\
\hline
\end{tabular}

\begin{tabular}{|c|c|c|c|c|c|}
\hline & bias & tang: & afa & net & y \\
\hline & \multicolumn{5}{|l|}{} \\
\hline Pola1 & 1 & 1 & 1 & 147 & 1 \\
\hline Pola2 & 1 & -1 & 1 & -67 & -1 \\
\hline Pola3 & 1 & -1 & 1 & -51 & -1 \\
\hline Pola4 & 1 & -1 & 1 & -47 & -1 \\
\hline Pola5 & 1 & -1 & 1 & -19 & -1 \\
\hline
\end{tabular}

Gambar 2. Epoch Pertama dan Kedua Huruf Ma

Pengenalan pola pertama huruf hiragana ma pada epoch pertama didapatkan nilai $\mathrm{f}(\mathrm{net})$ atau y belum sesuai nilai target $(\mathrm{t})$ sehingga dilanjutkan pada iterasi berikutnya yaitu epoch kedua. Pada epoch kedua didapatkan nilai $\mathrm{f}(\mathrm{net})$ atau y sudah sesuai nilai target $(\mathrm{t})$ sehingga pola pertama yaitu huruf hiragana ma sudah dapat dikenali.

\section{B. Pola Huruf Hiragana Mi dalam Excel}

\begin{tabular}{|c|c|c|c|c|c|}
\hline & bias & target & alfs & net & $y$ \\
\hline$P_{0}=1$ & 1 & 1 & 1 & 0 & 0 \\
\hline Pola 2 & 1 & 1 & 1 & .7 & -1 \\
\hline Pola 3 & 1 & 1 & 1 & -34 & 1 \\
\hline Pola 4 & 1 & 1 & 1 & 2) & 1 \\
\hline Pola 5 & 1 & -1 & 2 & -125 & +1 \\
\hline
\end{tabular}

\begin{tabular}{|lc|c|c|cc|}
\hline & bas & target & elf3 & net & $y$ \\
\hline \multicolumn{7}{|l|}{} \\
\hline Pola1 & 1 & -1 & 1 & -217 & $\vdots$ \\
\hline Pola2 & 1 & 1 & 1 & 141 & 1 \\
\hline Pola3 & 1 & -1 & 1 & -45 & -1 \\
\hline Pola4 & 1 & -1 & 1 & -159 & -1 \\
\hline Pola5 & 1 & -1 & 1 & -107 & 1 \\
\hline
\end{tabular}

Gambar 3. Epoch Pertama dan Kedua Huruf Mi

Pengenalan pola kedua huruf hiragana Mi pada epoch pertama didapatkan nilai f(net) atau y belum sesuai nilai target $(\mathrm{t})$ sehingga dilanjutkan pada epoch kedua. Pada epoch kedua didapatkan nilai $\mathrm{f}(\mathrm{net})$ atau $\mathrm{y}$ sudah sesuai dengan nilai target $(\mathrm{t})$ sehingga sehingga untuk pola huruf hiragana Mi sudah dapat ditemukan. 


\section{Pola Huruf Hiragana Mu dalam Excel}

\begin{tabular}{|c|c|c|c|c|c|}
\hline & bias & target & alta & net & $y$ \\
\hline & \multicolumn{5}{|l|}{} \\
\hline Pola1 & 1 & -1 & 1 & 0 & 0 \\
\hline Pola2 & 1 & -1 & 1 & -7 & 1 \\
\hline Pola3 & 1 & 1 & 1 & -43 & 1 \\
\hline Pola4 & 1 & -1 & 1 & 2 & 1 \\
\hline Pola5 & 1 & -1 & 1 & 43 & -1 \\
\hline
\end{tabular}

\begin{tabular}{|c|c|c|c|c|c||}
\hline & bias & tarzet & alfa & ret & $y$ \\
\hline & \multicolumn{5}{|c||}{} \\
\hline Ecla1 & 1 & -1 & 1 & -181 & -1 \\
\hline Pola2 & 1 & -1 & 1 & -39 & -1 \\
\hline Pola3 & 1 & $\vdots$ & 1 & 141 & $\vdots$ \\
\hline Pola7 & 1 & -1 & 1 & -199 & -1 \\
\hline Pola 5 & 1 & -1 & 1 & -15 & -1 \\
\hline
\end{tabular}

Gambar 4. Epoch Pertama dan Kedua Huruf Mu

Pengenalan pola ketiga huruf hiragana Mu pada epoch pertama didapatkan nilai $\mathrm{f}($ net) atau y belum sesuai nilai target $(\mathrm{t})$ sehingga dilanjutkan pada epoch kedua. Pada epoch kedua didapatkan nilai $\mathrm{f}($ net) atau y sudah sesuai dengan nilai target (t) sehingga sehingga untuk pola huruf hiragana Mu sudah dapat ditemukan.

\section{Pola Huruf Hiragana Me dalam Excel}

\begin{tabular}{|c|c|c|c|c|c|}
\hline & bas & tagket & difo & ne: & $y$ \\
\hline Pole $=$ & 1 & -1 & 1 & 0 & 0 \\
\hline Fola 2 & 1 & .1 & 1 & .7 & 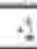 \\
\hline Fola 3 & 1 & -1 & 1 & 49 & +1 \\
\hline Fola $C$ & 1 & 1 & 1 & .27 & +2 \\
\hline Fola 5 & 1 & -1 & 1 & 66 & 1 \\
\hline
\end{tabular}

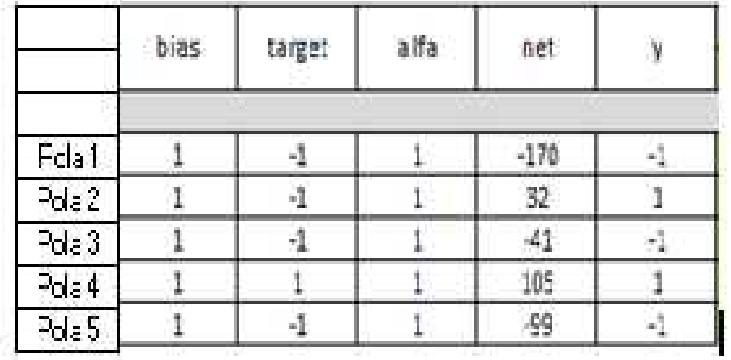

\begin{tabular}{|c|cc|c|c|c|}
\hline & bias & tartet & alfa & net & $y$ \\
\hline & \multicolumn{5}{|c|}{} \\
\hline Jola1 & 1 & -1 & 1 & -177 & -1 \\
\hline$P_{5}=2$ & 1 & -1 & 1 & -155 & -1 \\
\hline$P_{5}=3$ & 1 & -1 & 1 & -31 & -1 \\
\hline$P_{5}=4$ & 1 & 1 & 1 & 105 & 1 \\
\hline$P_{5}=5$ & 1 & -1 & 1 & -99 & -1 \\
\hline
\end{tabular}

Gambar 5. Epoch Pertama, Kedua dan Ketiga Huruf Me

Pengenalan pola keempat huruf hiragana Me pada epoch pertama didapatkan nilai f(net) atau y belum sesuai nilai target $(\mathrm{t})$ sehingga dilanjutkan pada epoch kedua. Pada epoch kedua didapatkan nilai $\mathrm{f}(\mathrm{net})$ atau $\mathrm{y}$ belum sesuai dengan nilai target $(\mathrm{t})$ sehingga harus lanjut pada epoch ketiga. Pada epoch ketiga didapatkan nilai $\mathrm{f}(\mathrm{net})$ atau $\mathrm{y}$ sesuai dengan nilai target $(\mathrm{t})$ sehingga untuk pola huruf hiragana Me sudah dapat ditemukan. 


\section{E. Pola Huruf Hiragana Mo dalam Excel}

\begin{tabular}{|c|c|c|c|c|c|}
\hline & bias & taiget & aifa & net & $v$ \\
\hline & 1 & -1 & 1 & 0 & 0 \\
\hline Pola 1 & 1 & -1 & 1 & -7 & -1 \\
\hline Pola 2 & 1 & -1 & 1 & -43 & -1 \\
\hline Pola 3 & 1 & -1 & 1 & -27 & 4 \\
\hline Pola 4 & 1 & -1 & 1 & -103 & -1 \\
\hline Pola 5 & 1 & 1 & 1 &
\end{tabular}

\begin{tabular}{|c|c|c|c|c|c|}
\hline & \multirow{2}{*}{ tias } & target & aifa & net & $y$ \\
\hline & 1 & -1 & 1 & -94 & -1 \\
\hline Pola 1 & 1 & -1 & 1 & 10 & 1 \\
\hline Pola2 & 1 & -1 & 1 & 49 & 1 \\
\hline Pola3 & 1 & -1 & 1 & -74 & -1 \\
\hline Pola 4 & 1 & 1 & 1 & -36 & -1 \\
\hline Pola 5 & 1 & 1 &
\end{tabular}

\begin{tabular}{|c|c|c|c|c|c|}
\hline & bias & tarket & alfo & net & $y$ \\
\hline & \multicolumn{5}{|l|}{} \\
\hline Pola 1 & 1 & -1 & 1 & -41 & -1 \\
\hline Pola 2 & 1 & -1 & 1 & -167 & -1 \\
\hline Pola3 & 1 & -1 & 1 & -35 & -1 \\
\hline Pola4 & 1 & -1 & 1 & -43 & -1 \\
\hline Pola5 & 1 & 1 & 1 & 153 & 1 \\
\hline
\end{tabular}

Gambar 6. Epoch Pertama, Kedua dan Ketiga Huruf Mo

Pengenalan pola kelima huruf hiragana Mo pada epoch pertama didapatkan nilai $f(n e t)$ atau y belum sesuai nilai target $(\mathrm{t})$ sehingga dilanjutkan pada epoch kedua. Pada epoch kedua didapatkan nilai $\mathrm{f}(\mathrm{net})$ atau y belum sesuai dengan nilai target $(\mathrm{t})$ sehingga harus lanjut pada epoch ketiga. Pada epoch ketiga didapatkan nilai $f(n e t)$ atau y sesuai dengan nilai target (t) sehingga untuk pola huruf hiragana Mo sudah dapat ditemukan.

\section{F. Implementasi Pola Huruf Ma dalam Program}

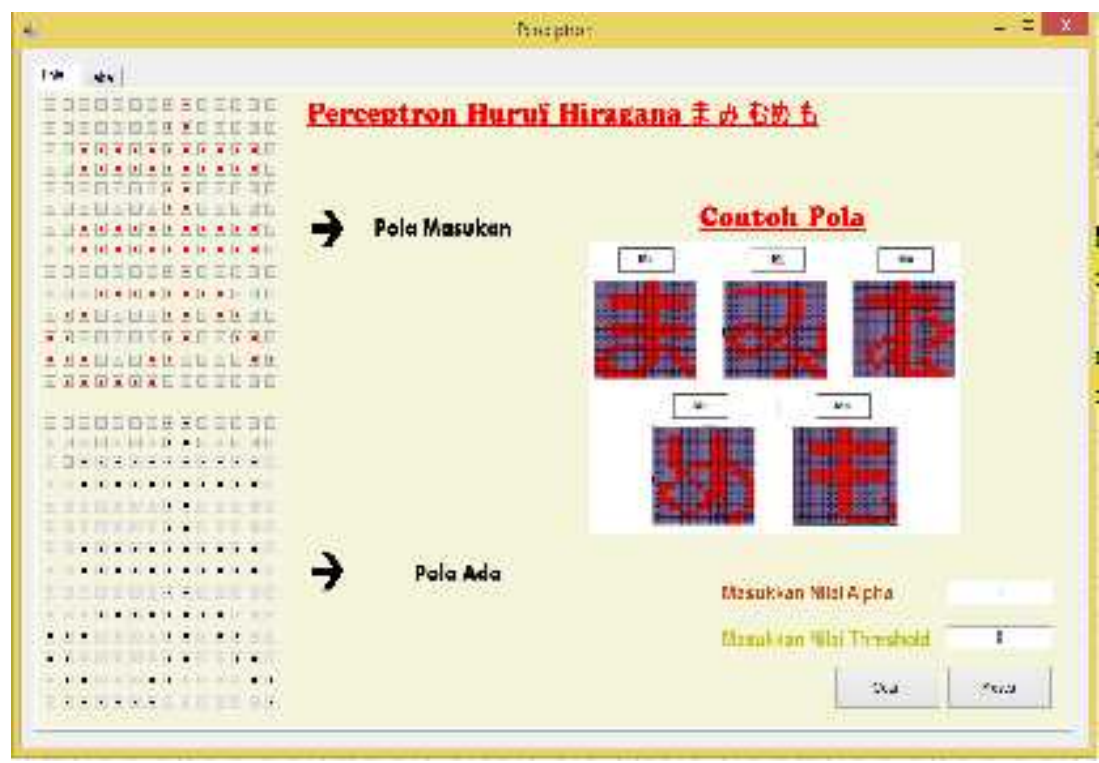

Gambar 7. Pola Huruf Ma Ditemukan 


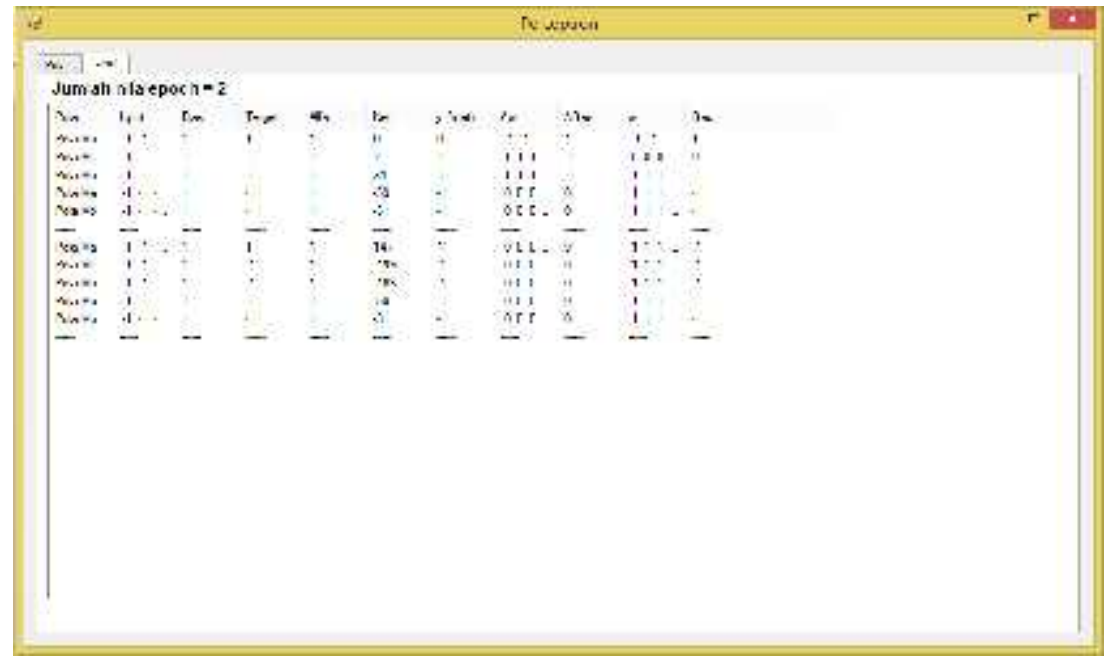

Gambar 8. Jumlah Epoch Huruf Ma dalam Program

Pada pengenalan pola pertama yakni pola huruf hiragana ma dengan memasukkan pola yang telah ditentukan. Selanjutnya, pada program ini ditentukan nilai alfa $(\alpha)$ sebesar $0,2,0,4,0,6,0,8$ dan 1 untuk mencari apakah ada perbedaan ketika nilai alfa tersebut dirubah, selain itu untuk nilai threshold $=0$, dan eksekusi pengenalan pola untuk mencapai target sesuai dengan nilai $f(n e t)$ atau $y$. Pada pola huruf hiragana ma ini eksekusi pengenalan pola pertama ini berhenti pada epoch kedua di mana target $(1,-1,-1,-1,-1)$ telah sesuai dengan $\mathrm{f}($ net) adalah $1,-1,-1,-1,-1$ meskipun jika nilai pada alfa telah dirubah dari 0,2 sampai dengan 1. Namun nilai net akan berubah ketika nilai masukan alfa dirubah dari 0,2 sampai dengan 1 .

\section{G. Implementasi Pola Huruf Mi dalam Program}

Pada pengenalan pola kedua yakni pola huruf hiragana mi dengan memasukkan pola yang telah ditentukan. Selanjutnya, pada program ini ditentukan nilai alfa $(\alpha)$ sebesar $0,2,0,4,0,6,0,8$ dan 1 untuk mencari apakah ada perbedaan ketika nilai alfa tersebut dirubah, selain itu untuk nilai threshold $=0$, dan eksekusi pengenalan pola untuk mencapai target sesuai dengan nilai $f(n e t)$ atau $y$. Pada pola huruf hiragana ma ini eksekusi pengenalan pola pertama ini berhenti pada epoch kedua di mana target $(1,-1,-1,-1,-1)$ telah sesuai dengan $\mathrm{f}($ net) adalah $1,-1,-1,-1,-1$ meskipun jika nilai pada alfa telah dirubah dari 0,2 sampai dengan 1. Namun nilai net akan berubah ketika nilai masukan alfa dirubah dari 0,2 sampai dengan 1 . Untuk hasil program bias dilihat pada gambar 9 dan 10 .

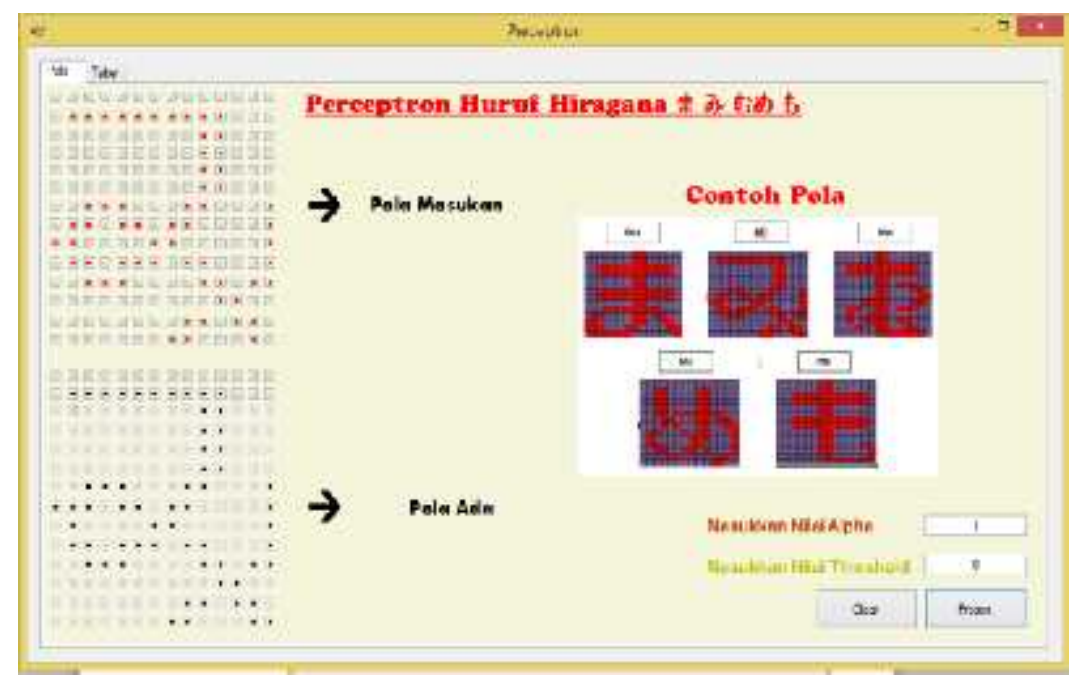

Gambar 9. Pola Huruf Mi Ditemukan 


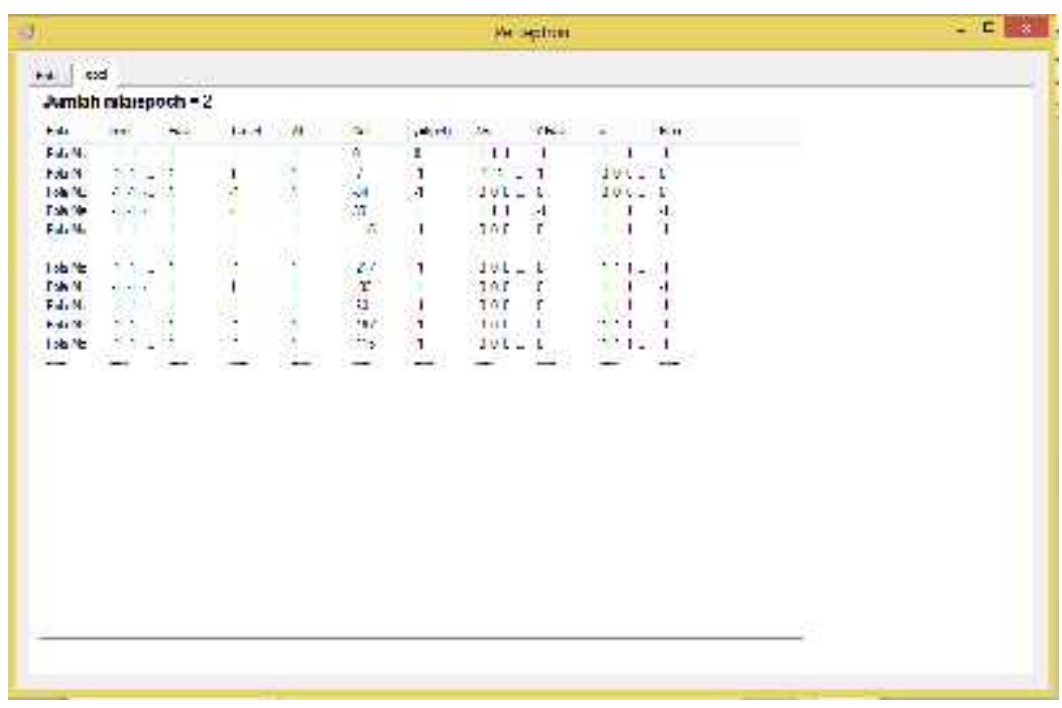

Gambar 10. Jumlah Epoch Huruf Mi dalam Program

\section{H. Implementasi Pola Huruf Mu dalam Program}

Pada pengenalan pola ketiga yakni pola huruf hiragana mu dengan memasukkan pola yang telah ditentukan. Selanjutnya, pada program ini ditentukan nilai alfa $(\alpha)$ sebesar $0,2,0,4,0,6,0,8$ dan 1 untuk mencari apakah ada perbedaan ketika nilai alfa tersebut dirubah, selain itu untuk nilai threshold $=0$, dan eksekusi pengenalan pola untuk mencapai target sesuai dengan nilai $\mathrm{f}(\mathrm{net})$ atau y. Pada pola huruf hiragana ma ini eksekusi pengenalan pola pertama ini berhenti pada epoch kedua di mana target $(-1,-1,1,-1,-1)$ telah sesuai dengan $\mathrm{f}($ net) adalah -1, -1, 1, -1, -1 meskipun jika nilai pada alfa telah dirubah dari 0,2 sampai dengan 1. Namun nilai net akan berubah ketika nilai masukan alfa dirubah dari 0,2 sampai dengan 1 . Untuk hasil program bias dilihat pada gambar 11 dan gambar 12 .

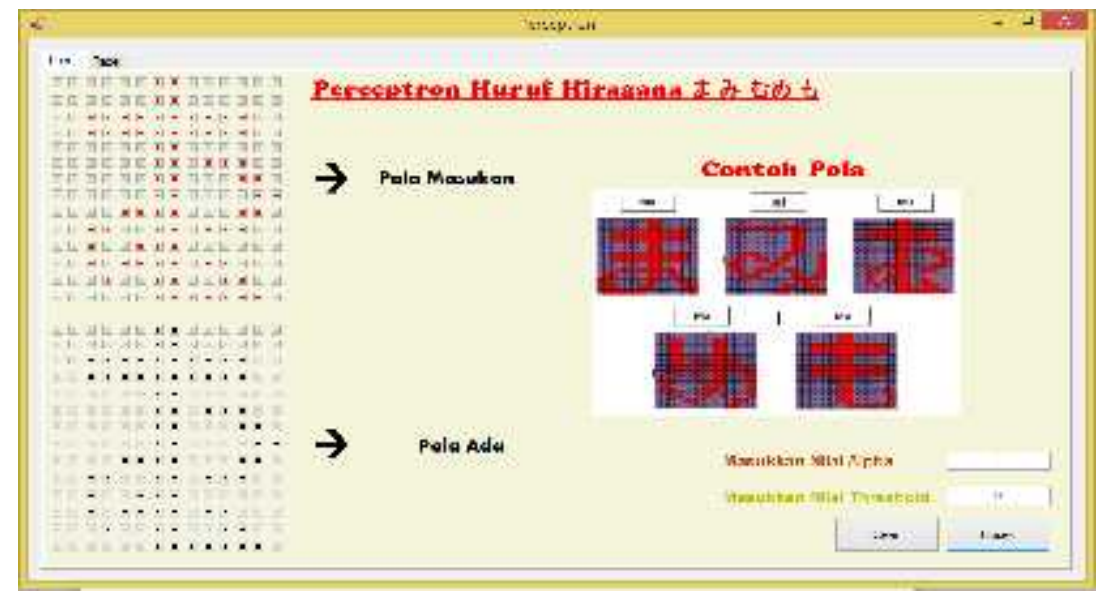

Gambar 11. Pola Huruf Mu Ditemukan 


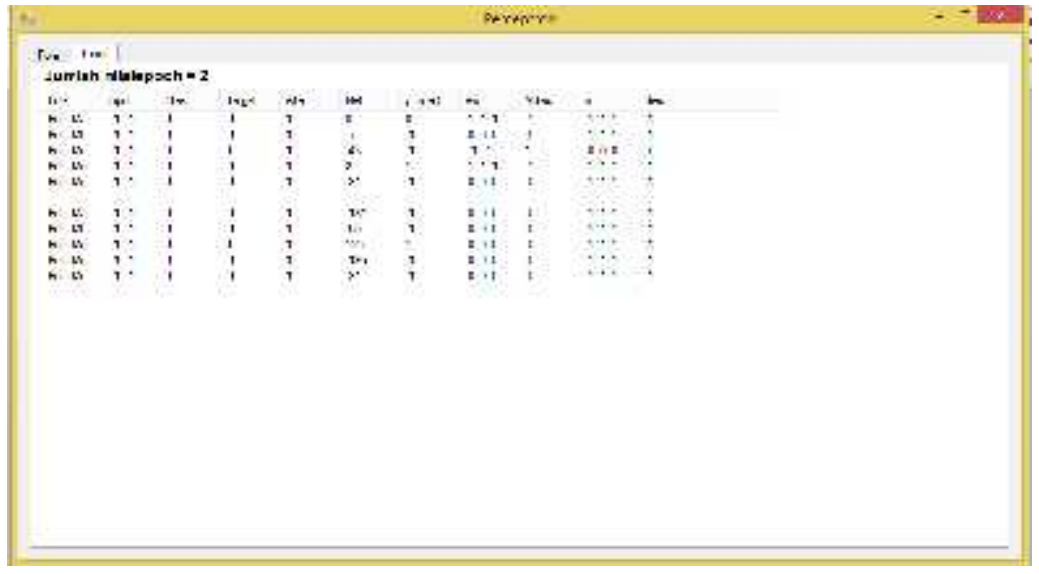

Gambar 12. Jumlah Epoch Huruf Mu dalam Program

\section{Implementasi Pola Huruf Me dalam Program}

Pada pengenalan pola keempat yakni pola huruf hiragana me dengan memasukkan pola yang telah ditentukan. Selanjutnya, pada program ini ditentukan nilai alfa $(\alpha)$ sebesar 0,2, 0,4 , 0,6, 0,8 dan 1 untuk mencari apakah ada perbedaan ketika nilai alfa tersebut dirubah, selain itu untuk nilai threshold $=0$, dan eksekusi pengenalan pola untuk mencapai target sesuai dengan nilai $\mathrm{f}$ (net) atau $\mathrm{y}$. Pada pola huruf hiragana ma ini eksekusi pengenalan pola pertama ini berhenti pada epoch kedua di mana target $(-1,-1,-1,1,-1)$ telah sesuai dengan $\mathrm{f}(\mathrm{net})$ adalah $-1,-1,-1,1,-1$ meskipun jika nilai pada alfa telah dirubah dari 0,2 sampai dengan 1. Namun nilai net akan berubah ketika nilai masukan alfa dirubah dari 0,2 sampai dengan 1 . Untuk hasil program bias dilihat pada gambar 13 dan 14.

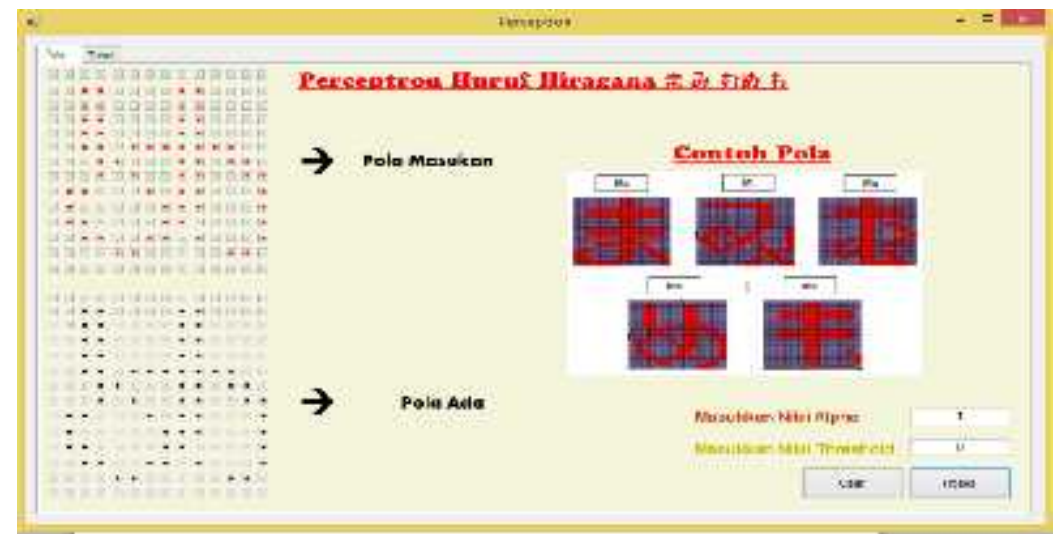

Gambar 13. Pola Huruf Me Ditemukan

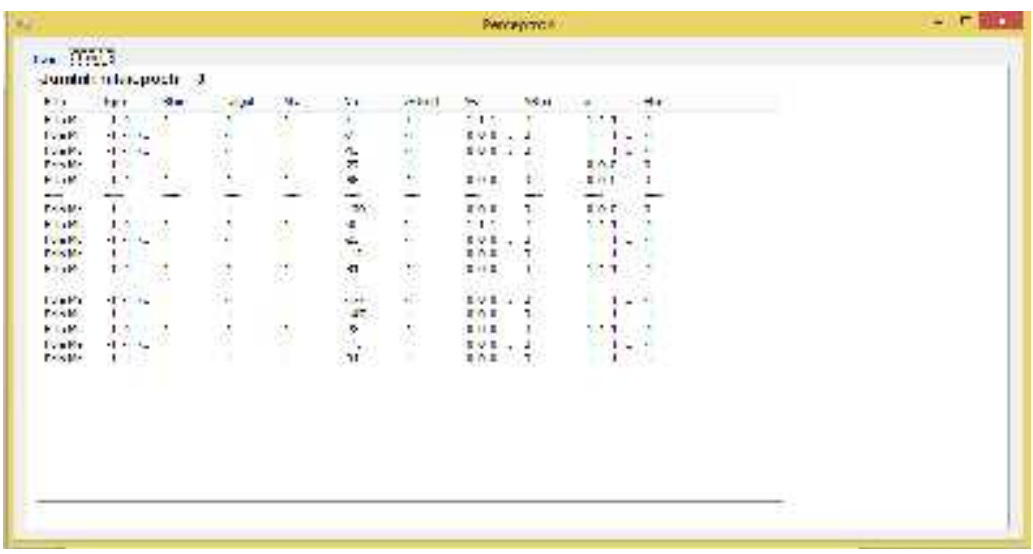

Gambar 14. Jumlah Epoch Huruf Me dalam Program 


\section{J. Implementasi Pola Huruf Mo dalam Program}

Pada pengenalan pola kelima yakni pola huruf hiragana me dengan memasukkan pola yang telah ditentukan. Selanjutnya, pada program ini ditentukan nilai alfa $(\alpha)$ sebesar $0,2,0,4,0,6,0,8$ dan 1 untuk mencari apakah ada perbedaan ketika nilai alfa tersebut dirubah, selain itu untuk nilai threshold $=0$, dan eksekusi pengenalan pola untuk mencapai target sesuai dengan nilai $f(n e t)$ atau y. Pada pola huruf hiragana ma ini eksekusi pengenalan pola pertama ini berhenti pada epoch ketiga di mana target $(-1,-1,-1,-1,1)$ telah sesuai dengan $\mathrm{f}($ net) adalah $-1,-1,-1,-1,1$ meskipun jika nilai pada alfa telah dirubah dari 0,2 sampai dengan 1. Namun nilai net akan berubah ketika nilai masukan alfa dirubah dari 0,2 sampai dengan 1 . Untuk hasil program bias dilihat pada gambar 15 dan 16.

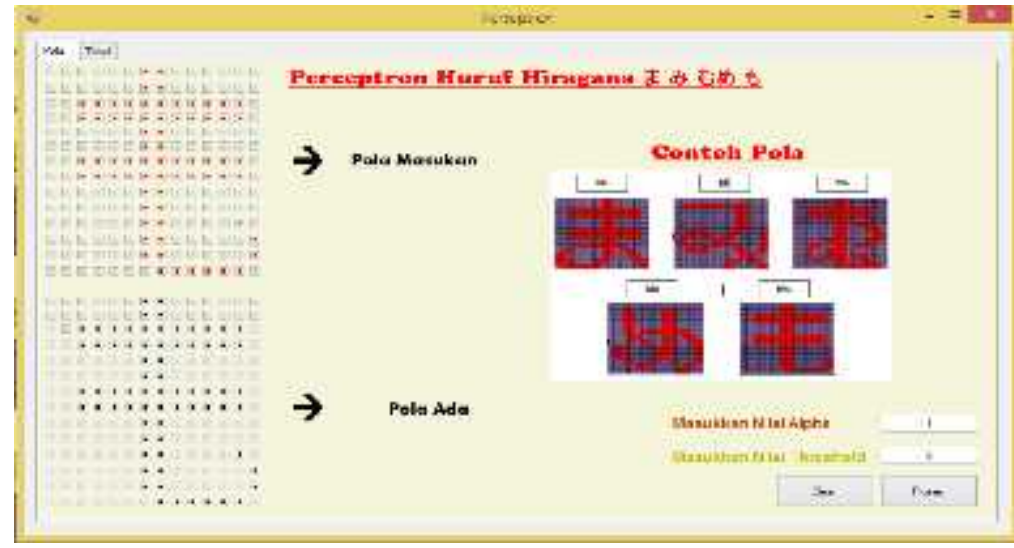

Gambar 15. Pola Huruf Me Ditemukan

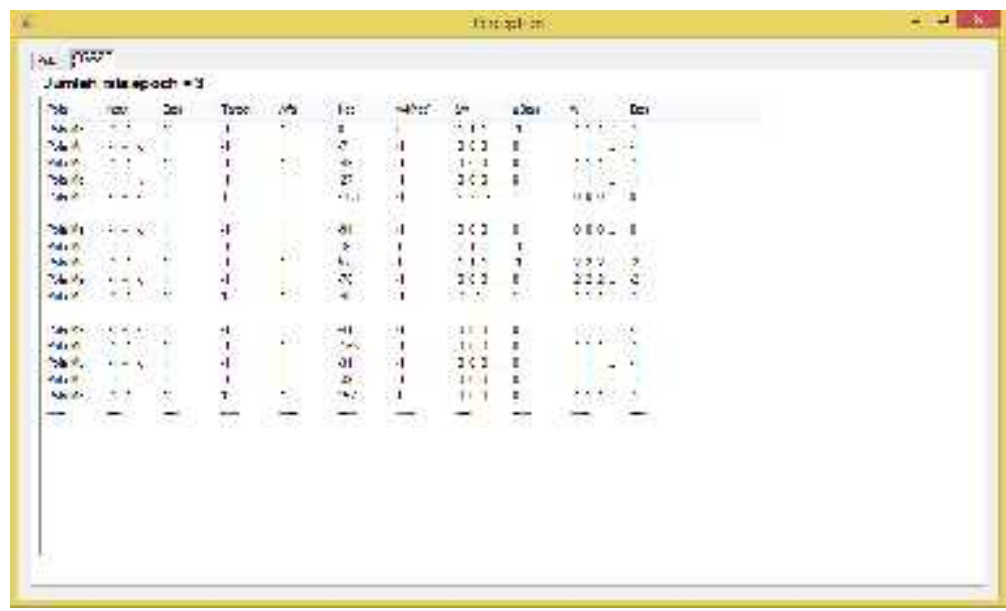

Gambar 16. Jumlah Epoch Huruf Mo dalam Program

\section{K. Analisis Excel dan Program}

Hasil pengenalan pola pulau-pulau besar di Indonesia, berdasarkan perhitungan baik secara manual menggunakan program excel ataupun implementasi pada program VB dalam Jaringan Saraf Tiruan (JST) model jaringan perceptron, didapatkan hasil yang sama dalam pengenalan pola, tabulasi data hasil ditunjukkan pada Tabel 2 dan Tabel 3 berikut.

Tabel 2. Inputan Pengenalan Huruf

\begin{tabular}{lll}
\hline \multirow{2}{*}{ Pola } & \multicolumn{2}{c}{ Perhitungan } \\
\cline { 2 - 3 } & $\begin{array}{c}\text { Inputan Pada } \\
\text { Excel }\end{array}$ & $\begin{array}{c}\text { Inputan Pada } \\
\text { VB }\end{array}$ \\
\hline Huruf Ma & Nilai $(w)=0$ & Nilai $(\mathrm{w})=0$ \\
& Nilai $(\alpha)=1$ & Nilai $(\alpha)=1$ \\
& Nilai $(\theta)=0$ & Nilai $(\theta)=0$ \\
\hline Huruf Mi & Nilai $(\mathrm{w})=0$ & Nilai $(\mathrm{w})=0$ \\
& Nilai $(\alpha)=1$ & Nilai $(\alpha)=1$ \\
\hline
\end{tabular}




\begin{tabular}{lll}
\hline & Nilai $(\theta)=0$ & Nilai $(\theta)=0$ \\
\hline Huruf Mu & Nilai $(w)=0$ & Nilai $(w)=0$ \\
& Nilai $(\alpha)=1$ & Nilai $(\alpha)=1$ \\
& Nilai $(\theta)=0$ & Nilai $(\theta)=0$ \\
\hline Huruf Me & Nilai $(w)=0$ & Nilai $(w)=0$ \\
& Nilai $(\alpha)=1$ & Nilai $(\alpha)=1$ \\
& Nilai $(\theta)=0$ & Nilai $(\theta)=0$ \\
\hline Huruf Mo & Nilai $(w)=0$ & Nilai $(w)=0$ \\
& Nilai $(\alpha)=1$ & Nilai $(\alpha)=1$ \\
& Nilai $(\theta)=0$ & Nilai $(\theta)=0$ \\
\hline
\end{tabular}

Tabel 3. Hasil Perbandingan Pola Huruf

\begin{tabular}{lccc}
\hline \multirow{1}{*}{ Pola } & \multicolumn{2}{c}{ Perhitungan } & \\
\cline { 2 - 3 } & $\begin{array}{c}\text { Hasil } \\
\text { Pada } \\
\text { Excel } \\
\text { (epoch) }\end{array}$ & $\begin{array}{c}\text { Hasil } \\
\text { Pada } \\
\text { VB(epoc } \\
\text { h) }\end{array}$ & Selisih \\
\hline Huruf Ma & 2 & 2 & 0 \\
\hline Huruf Mi & 2 & 2 & 0 \\
\hline Huruf Mu & 2 & 2 & 0 \\
\hline Huruf Me & 3 & 3 & 0 \\
\hline Huruf Mo & 3 & 3 & 0 \\
\hline
\end{tabular}

Berdasarkan Tabel 2 dan Tabel 3 dapat dijelaskan bahwa pada pengenalan pola huruf hiragana ma, mi, $\mathrm{mu}$, me dan mo didapatkan hasil yang sama antara perhitungan manual menggunakan excel dan implementasi pada program VB dengan selisih 0, sehingga dapat disimpulkan bahwa terjadi keakurasian antara keduanya.

Tabel 4. Perbandingan Pola Huruf dengan Nilai Alfa Berbeda

\begin{tabular}{|c|c|c|c|c|c|c|c|c|c|}
\hline Pola & Alfa & $\begin{array}{c}\text { Net } \\
\text { Terakhir }\end{array}$ & $\begin{array}{c}\text { Jumlah } \\
\text { Epoch }\end{array}$ & Selisih & Pola & Alfa & $\begin{array}{c}\text { Net } \\
\text { Terakhir }\end{array}$ & $\begin{array}{c}\text { Jumlah } \\
\text { Epoch }\end{array}$ & Selisih \\
\hline \multirow{26}{*}{$\mathrm{Ma}$} & \multirow[t]{5}{*}{0,25} & 36,75 & \multirow{5}{*}{2} & \multirow{20}{*}{0} & \multirow{20}{*}{ Mi } & \multirow[t]{5}{*}{0,25} & 54,25 & \multirow{5}{*}{2} & \multirow{20}{*}{0} \\
\hline & & $-49,75$ & & & & & 33,25 & & \\
\hline & & $-40,75$ & & & & & $-15,75$ & & \\
\hline & & $-14,75$ & & & & & $-41,75$ & & \\
\hline & & $-7,75$ & & & & & $-28,75$ & & \\
\hline & \multirow[t]{5}{*}{0,5} & 73,5 & \multirow{5}{*}{2} & & & \multirow[t]{5}{*}{0,5} & 108,5 & \multirow{5}{*}{2} & \\
\hline & & $-99,5$ & & & & & $-66,5$ & & \\
\hline & & $-81,5$ & & & & & $-31,5$ & & \\
\hline & & $-29,5$ & & & & & $-83,5$ & & \\
\hline & & $-15,5$ & & & & & $-57,5$ & & \\
\hline & \multirow[t]{5}{*}{0,75} & 110,25 & & & & \multirow[t]{5}{*}{0,75} & $-162,25$ & & \\
\hline & & $-149,25$ & & & & & 99,75 & & \\
\hline & & $-122,25$ & 2 & & & & $-47,25$ & 2 & \\
\hline & & $-44,25$ & & & & & $-125,25$ & & \\
\hline & & $-23,25$ & & & & & $-86,25$ & & \\
\hline & \multirow[t]{5}{*}{1} & 147 & \multirow{5}{*}{2} & & & \multirow[t]{5}{*}{1} & 217 & \multirow{5}{*}{2} & \\
\hline & & -199 & & & & & -133 & & \\
\hline & & -163 & & & & & -63 & & \\
\hline & & -59 & & & & & -167 & & \\
\hline & & -31 & & & & & -115 & & \\
\hline & \multirow[t]{5}{*}{0,25} & $-45,25$ & \multirow{6}{*}{2} & \multirow{6}{*}{0} & \multirow{6}{*}{$\mathrm{Me}$} & 0,25 & $-44,75$ & & \multirow{6}{*}{0} \\
\hline & & $-13,75$ & & & & & $-36,75$ & & \\
\hline & & 31,25 & & & & & $-5,75$ & 3 & \\
\hline & & $-48,75$ & & & & & 28,25 & & \\
\hline & & $-7,75$ & & & & & $-22,75$ & & \\
\hline & 0,5 & $-90,5$ & & & & 0,5 & 88,5 & & \\
\hline
\end{tabular}




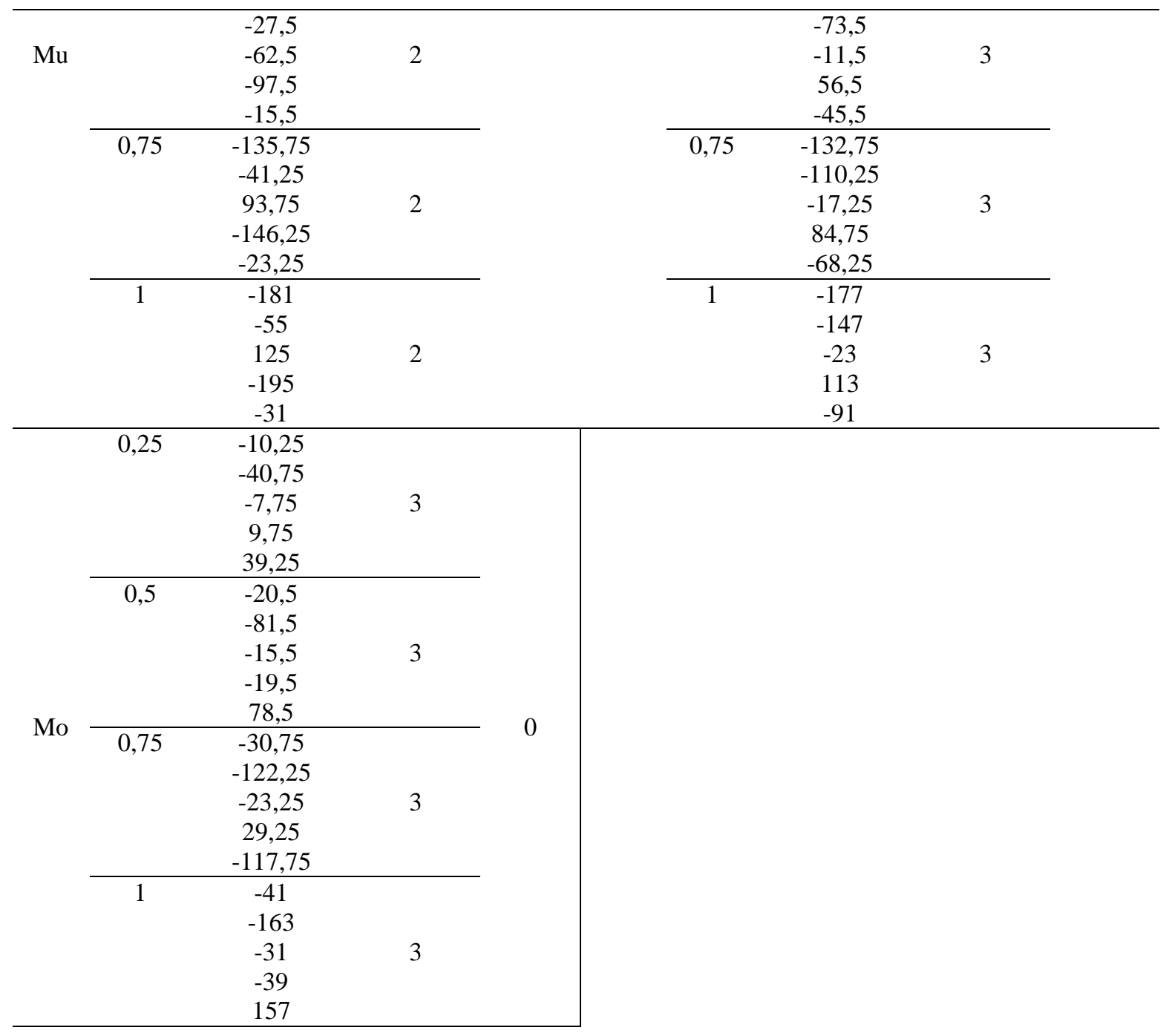

Berdasarkan Tabel 4 dapat dijelaskan bahwa pada pengenalan pola huruf hiragana ma, mi, mu, me dan mo didapatkan hasil yang sama antara net yang berbeda-beda ketika nilai alfa dirubah. Namun untuk jumlah epochnya memiliki selisih 0 yang berarti ketika nilai alfa dirubah tidak akan mempengaruhi jumlah epoch untuk tiap-tiap pola huruf.

\section{KESIMPULAN DAN SARAN}

Penggunaan Jaringan Saraf Tiruan (JST) dengan model jaringan perceptron dapat digunakan untuk penentuan pengenalan pola karakter, simbol dan lain sebagainya, termasuk pola pulau-pulau besar di Indonesia. Penentuan pengenalan pola tersebut berdasarkan 5 inputan yang harus dimasukkan yaitu nilai bobot $(\mathrm{w})=0$, nilai alpha $(\alpha)=1$, dan nilai threshold $(\theta)=0$ untuk analisis pertama. Sedangkan untuk analisis kedua menggunakan nilai nilai bobot $(\mathrm{w})=0$, nilai alpha $(\alpha)=0,25,0,5,0,75$, dan 1 , dan nilai threshold $(\theta)=0$

Kesimpulan dari hasil pengenalan pola huruf hiragana dari kedua tipe analisis yaitu yang pertama menggunakan program dan excel mendapatkan hasil yang sama untuk jumlah epochnya. Sedangkan untuk analisis kedua yaitu dengan mengganti nilai alfa juga mendapatkan hasil epoch yang sama, Saran untuk penelitian atau pengembangan selanjutnya yaitu mengembangkan program dengan fungsi lebih banyak dengan menggunakan metode perceptron.

\section{DAFTAR PUSTAKA}

[1] Afriyanti, L. 2010. Rancang Bangun Tool Untuk Jaringan Syaraf Tiruan (JST) Model Perceptron. Makalah disajikan dalam Seminar Nasional Aplikasi Teknologi Informasi, Yogyakarta, 19Juni 2010. 
[2] Asri, Y. Penerapan Aturan Perceptron Pada Jaringan Saraf Tiruan dalam Pengenalan Pola Penyakit Mata. 2011. Jurnal Pengkajuan dan Penerapan Teknik Informatika. 4(2): 140-146.

[3] David. Perancangan Perangkat Lunak Pengenalan PolaKarakter Menggunakan Jaringan Syaraf TiruanPerceptron. 2011. Jurnal Ilmiah SISFOTENIKA. 1(1): 10-19.

[4] Hartantri, F., R., Pujiyanta, A. Deteksi Penyakit Dan Serangan Hama Tanaman Buah Salak Menggunakan Jaringan Syaraf Tiruan (JST) dengan Metode Perceptron. 2014. Jurnal Sarjana Teknik Informatika. 2(2): 1228-1240.

[5] Kurniawan, Z., H. Faktor Penyebab Kesulitan Belajar Bahasa Jepang Siswa SMA Negeri 15 Semarang. 2015. Semarang: Universitas Negeri Semarang. Skripsi tidak diterbitkan.

[6] Pujiyanta, A. Pengenalan Citra Objek Sederhana Dengan Jaringan SarafTiruan Metode Perceptron. 2009. Jurnal Informatika. 3(1): 2009.

[7] Septiarini, A. 2012. Sistem Pengenalan Karakter Dengan Jaringan Syaraf Tiruan Algoritma Perceptron. Jurnal Informatika Mulawarman. 7(3): 105-109. 